\title{
Recycling nutrients from horse manure: effects of bedding type and its compostability
}

\author{
Riikka Keskinen ${ }^{1}$, Markku Saastamoinen², Johanna Nikama ${ }^{1}$, Susanna Särkijärvi², Marianna Myllymäki², Tapio Salo \\ Jaana Uusi-Kämppä ${ }^{1}$ \\ ${ }^{1}$ Natural Resources Institute Finland (Luke), Management and Production of Renewable Resources, Tietotie 4, Fl-31600 \\ Jokioinen, Finland \\ ${ }^{2}$ Natural Resources Institute Finland (Luke), Green Technology, Opistontie 10 A 1, Fl-32100 Ypäjä, Finland \\ riikka.keskinen@luke.fi
}

\begin{abstract}
Manure constitutes a nutrient resource that should be efficiently recycled in agriculture. We assessed the nutrient cycling properties of three bedding materials (peat, wood shavings and pelleted straw) in horse manure by comparing their compostability, ability to retain nitrogen $(N)$ and phosphorus $(P)$ under rainfall and capacity to release $\mathrm{N}$ when mixed with soil. Manure with pelleted straw bedding had superior composting characteristics as it lost half of its dry mass, reached temperatures $>60^{\circ} \mathrm{C}$ and ended up having a carbon (C) to $\mathrm{N}(\mathrm{C}: \mathrm{N})$ ratio of $<15$. In percolated water, $4-11 \%$ of total manure $\mathrm{N}$ and $5-23 \%$ of total manure $\mathrm{P}$ was leached during a $2 \mathrm{~h} 15 \mathrm{~min}$ event of artificial rainfall. Peat manure was most susceptible to $\mathrm{P}$ loss. In all fresh manures, $\mathrm{C}: \mathrm{N}$ ratio exceeded 30 , which led to net $\mathrm{N}$ immobilization in soil. Composting decreased the C:N leading to a slight positive or an insignificant fertilizer effect.
\end{abstract}

Key words: horse manure, bedding material, nutrient cycling, composting

\section{Introduction}

The equine sector has increased globally during the last decades and currently about 6 million hobby and sports horses reside in the EU member states (EPMA 2009, EHN 2016). Manure produced by these horses constitutes a considerable nutrient resource. Based on average nitrogen (N) (Graham-Thiers and Bowen 2011) and phosphorus (P) (Ögren 2013, Fowler et al. 2015) concentrations, and an average daily production of about 12-17 kg dung (Jansson and Dahlborn 1999, Fowler et al. 2015) and 12 I urine (Toribio et al. 2007), the horses in EU can be calculated to excrete over 300 million $\mathrm{kg} \mathrm{N}$ and 48 million kg P annually. The $\mathrm{N}$ originates mainly from urine and $\mathrm{P}$ from dung (Schryver et al. 1971, Särkijärvi and Saastamoinen 2014).

Exploitation of horse manure in agri- and horticulture as a fertilizer or soil conditioner should be enhanced. To preserve the value of horse manure as a fertilizer, proper management, including choice of bedding material, handling, storing and end use is essential. If nutrients are leached due to poor manure handling, horse manure may pose a risk to local watercourses and finally to the Baltic Sea. In Finland, lot of horse stables and activities are placed on areas that are critical regarding leaching of nutrients to waters (Pussinen et al. 2007). Especially leaching of $P$ from horse manure or paddocks can be considered an environmental risk (Närvänen et al. 2008, Uusi-Kämppä et al. 2012, Parvage et al. 2015).

Under warm climatic conditions horses are commonly kept outdoors for several hours daily, but in northern cool climate, horses are exercised outside only a few hours during a winter day. Most of the dung and urine is thus produced in the stalls and mixed with the bedding material, which is applied to bind moisture and gases and afford a soft bed to the horses. The choice of bedding material has a marked effect on the properties of the manure since bedding makes up 60 to $80 \%$ of the manure volume depending on the material applied (Särkijärvi et al. 2004, Airaksinen 2006). Several choices are available for the bedding in horse stables, wood shavings, saw dust, peat, pelleted straw and straw being the most common ones. For the welfare of both horses and people working and visiting in stables, stall bedding should be hygienic, free from dust, able to absorb ammonia, and be easy and light to handle. From environmental perspective, the bedding should have high capacity to retain nutrients during use and storage but at the same time efficiently release them once recycled into agricultural soil.

Horse manure typically has a high carbon (C) to $N(C: N)$ ratio, meaning that decomposing microbes absorb released $\mathrm{N}$ to satisfy their growth requirements (Chen et al. 2014). Due to this net $\mathrm{N}$ immobilization, horse manure is not a desired fertilizer. However, due to beneficial effects on soil structure and $\mathrm{C}$ content, it can be considered a valuable soil conditioner (Sweeten and Mathers 1985). Composting, meaning biological aerobic decomposition, reduces the manure volume, moisture and odor, increases its uniformity, stability and concentration and eliminates pathogens, parasites and flies (Bernal et al. 2009). Handling, transport and utilization of manure can thus 
be enhanced by composting. Efficient composting of animal faeces requires the use of a $\mathrm{C}$ rich bulking agent to adjust both the nutrient balance and the physical structure of the substrate (Bernal et al. 2009). In horse manure, the bedding serves as the bulking agent.

In this study, horse manure with three bedding materials, peat, wood shavings and pelleted straw, was examined on the nutrient cycling point of view. The three manures were compared in relation to their $\mathrm{N}, \mathrm{P}$ and potassium (K) content, ability to store $\mathrm{N}$ and $\mathrm{P}$ during storage even under rainfall, compostability and ability to release $\mathrm{N}$ when used as a soil amendment. Bedding material makes up the bulk of horse manure and can thus be expected to govern the decomposition rate and nutrient cycling properties of the manure.

\section{Material and methods}

\section{Manure collection and composting}

Horse manure with three different commercial bedding materials, peat (Vapo Ltd., Finland), pine and spruce wood shavings (Hunter, Metsä Wood Ltd., Finland) and pelleted barley and wheat straw (Biolki Ltd., Finland), was collected during four consecutive one-week periods in January-February 2013. Six Finnhorse mares (mean body weight $555 \mathrm{~kg}$ ) used in the experiment were individually stabled in the research stables of Luke (former MTT Agrifood Research Finland) in Ypäjä, south-western Finland. The horses were fed with a typical Finnish hay-concentrate diet supplemented with a mineral-vitamin mixture according to the Finnish feeding recommendations (Luke 2017), and allowed free exercise in outdoor paddocks for about four hours daily. The four manure collection weeks, each forming one replicate for the study, were preceded by one test week. Over the five weeks, the horses were rotated in six stalls, of which two of each were bedded with one of the three different materials. Proper amount of bedding was applied to ensure adequate absorption of moisture, comfortableness of horses and easy maintenance. In total, $740 \mathrm{~kg}$ peat, $730 \mathrm{~kg}$ pelleted straw and $440 \mathrm{~kg}$ wood shavings were consumed.

Soiled bedding and dung were removed from the stalls daily by the same person. By bedding material, the manure removed was weighed and placed into a $0.5 \mathrm{~m}^{3}$ plastic storage box until the box was filled. The minor quantity of manure discarded was not recorded. At the end of each one-week collection period, the entire amount of manure acquired into each box was mixed thoroughly and thereafter sampled by combining several grab samples. The samples were frozen immediately after collection and stored at $-20^{\circ} \mathrm{C}$ until chemical analyses and further studies. In the middle part of each manure-filled box, two temperature sensors equipped with dataloggers and one bi-metallic thermometer were installed. The dataloggers recorded the manure temperature in every four hours, whereas the conventional thermometers were read weekly or when necessary for up-to-date monitoring.

During the week of manure collection, the storage boxes were kept inside the stable and immediately thereafter transported to a nearby storage barn. In the barn, the boxes were in outdoor temperature but protected from animals, wind and rain. The manures were let to compost between January and September, (in total 28-31 weeks). In the beginning of June and July, the manure piles were thoroughly aerated by turning with spades and pitchforks. During the latter turning, the masses were moistened with deionized water. In early September, the boxes were weighed to define the loss of dry mass and sampled by bulking 3-5 cores obtained by drilling through the compost pile. The samples were immediately frozen and stored at $-20^{\circ} \mathrm{C}$ until chemical analyses and further studies.

\section{Laboratory analyses}

The chemical composition of both fresh and composted manure samples was determined at Eurofins Viljavuuspalvelu Ltd (Mikkeli, Finland). The total concentration of N was analyzed by the Kjeldahl method (SFS-EN 13342:2000, SFS-EN 13654-1:2002) and total P and K by ICP after dry combustion (SFS-EN 15510:2008). The water soluble ammonium $-\mathrm{N}\left(\mathrm{NH}_{4}-\mathrm{N}\right)$, nitrate- $\mathrm{N}\left(\mathrm{NO}_{3}-\mathrm{N}\right)$, phosphate- $\mathrm{P}\left(\mathrm{PO}_{4}-\mathrm{P}\right)$ and total dissolved $\mathrm{N}$ and $\mathrm{P}$ were analyzed from 1:60 water extracts using a continuous flow analyzer (Aquakem 250). The total dissolved concentrations of $\mathrm{N}$ and $\mathrm{P}$ include both inorganic and organic compounds all converted to $\mathrm{NO}_{3}-\mathrm{N}$ or $\mathrm{PO}_{4}-\mathrm{P}$ by oxidative digestion with peroxodisulfate (SFS-EN ISO 11905-1). The total content of $C$ in the manures was determined via dry combustion (Dumas method) at Luke laboratories in Jokioinen. In addition, the bulk density of the samples was measured according to EN 13040. 


\section{Leaching studies}

For leaching studies with artificial rain, plastic containers $(\varnothing 270 \mathrm{~mm}$ ) equipped with bottom drainage runoff collection system were used. A one-cm layer of quartz sand, which was covered with $1 \times 1 \mathrm{~mm}$ plastic mesh, was laid at the bottom of the containers. On top of the mesh, a manure sample was weighed according to the volume weight of the material to obtain a three-litre sample volume, which corresponded to $0.28 \pm 0.05 \mathrm{~kg}$ manure dry mass $(\mathrm{dm})$ and formed an approximately $5 \mathrm{~cm}$-thick layer. The containers were positioned to have a $4 \%$ slope towards the drainage outlet while subjected to artificial rainfall of 8-10 $\mathrm{mm} \mathrm{h}^{-1}$ under a stationary drip type rainfall simulator (Uusitalo and Aura 2005) for a period of $2 \mathrm{~h} 15 \mathrm{~min}$. The percolated water was collected from the start of the rain until $10 \mathrm{~min}$ after its end. The raindrops of deionized water fell from a distance of $220 \mathrm{~cm}$. The manures were treated in groups of three arranged according to the week of manure collection (replicates 1-4) so that fresh and composted samples were treated separately including one replicate of each of the three bedding types into all batches. All the collected waters (24 samples in total) were weighed and analyzed for $\mathrm{NH}_{4}-\mathrm{N}$, $\mathrm{NO}_{3}-\mathrm{N}$, total $\mathrm{N}, \mathrm{PO}_{4}-\mathrm{P}$ and total $\mathrm{P}$ with a continuous flow analyzer (Lachat QuikChem IC+ 8000 Series) at the Luke laboratories in Jokioinen.

\section{$\mathrm{N}$ mineralization}

An incubation study was conducted according to ISO 14238 standard. Aliquots of both fresh and composted manure providing $100 \mathrm{mg}$ of $\mathrm{N} \mathrm{kg}^{-1}$ of soil (as total $\mathrm{N}$ ) were weighed and mixed with $600 \mathrm{~g}$ fine sand soil in a plastic container $(\varnothing 180 \mathrm{~mm})$. An additional $30 \mathrm{mg}$ of $\mathrm{N} \mathrm{kg}^{-1}$ soil was applied as ammoniumnitrate $\left(\mathrm{NH}_{4} \mathrm{NO}_{3}\right)$ to promote the decomposition process. The mean amount of total $\mathrm{P}$ introduced in the manure amendments ranged between 15 and $25 \mathrm{mg} \mathrm{kg}^{-1}$ soil. The soils were let to incubate at $20^{\circ} \mathrm{C}$. During the incubation the soils were thoroughly mixed twice a week concurrently adding deionized water to maintain a constant moisture level of $18.8 \%$. Subsamples were taken for $\mathrm{N}$ analyses after $0,7,14,28$ and $48 \mathrm{~d}$ of incubation. The samples were extracted immediately after collection with $1 \mathrm{M}$ potassium chloride $(\mathrm{KCl})$ solution (1:5 soil: solution ratio). $\mathrm{The}_{\mathrm{NH}}-\mathrm{N}$ and $\mathrm{NO}_{3}-\mathrm{N}$ concentrations of the extracts were determined with a continuous flow analyzer (Skalar San++ System) at the Luke laboratories in Jokioinen.

\section{Statistical analyses}

An analysis of variance was conducted to test for differences in the N, P and $\mathrm{K}$ concentrations and leaching losses of $\mathrm{N}$ and $\mathrm{P}$ under rain simulation between the peat, wood shavings and pelleted straw manures. The analyses were performed separately for fresh and composted manures. Individual means were compared using least significant difference (LSD). A pairwise $t$ test was used to study changes in selected characteristics of the manures during composting. The significance level was set at $5 \%$.

\section{Results}

\section{Nutrient content}

Of the three bedding materials studied, peat and pelleted straw contained inherently more $\mathrm{N}$ than wood shavings (Table 1). The proportion of water soluble $\mathrm{N}$ from the total $\mathrm{N}$ was around $5 \%$ in the clean peat and pelleted straw bedding and $15 \%$ in the wood shavings. The total $\mathrm{P}$ and especially $\mathrm{K}$ concentrations were higher in pelleted straw than in peat and wood shavings. Water soluble P comprised around $20-25 \%$ of the total P in the clean beddings.

In the fresh manures, the total $\mathrm{N}$ concentration was equal between peat and pelleted straw manure and somewhat lower in the wood shavings manure (Table 1). The water soluble $\mathrm{N}$ concentrations were at the same level in all the three manures. The proportion of water soluble $\mathrm{N}$ from total $\mathrm{N}$ was almost $40 \%$ in the wood shavings manure and around $30 \%$ in the peat and pelleted straw manures. Of the water soluble $\mathrm{N}$ in the fresh manures, $\mathrm{NH}_{4}-\mathrm{N}$ comprised roughly $40 \%$ in the pelleted straw manure, $55 \%$ in the wood shavings manure and $65 \%$ in the peat manure. Less than $1 \%$ of the water soluble $\mathrm{N}$ was found in the $\mathrm{NO}_{3}-\mathrm{N}$ form in all of the fresh manures. The remaining proportion of the soluble $\mathrm{N}$ was assumedly made up of organic $\mathrm{N}$ compounds.

The total $\mathrm{P}$ and $\mathrm{K}$ concentrations of the fresh manures were slightly higher in the pelleted straw than in the peat and wood shavings manures (Table 1 ). The water soluble $\mathrm{P}$ occurred nearly totally as inorganic $\mathrm{PO}_{4}-\mathrm{P}$ and comprised $45 \%$ of the total manure $P$ in the pelleted straw manure and $55-60 \%$ in the peat and wood shavings manures. 
In the composted manures, the total $\mathrm{N}$ and $\mathrm{P}$ concentrations of the pelleted straw were roughly double to those in the peat and wood shavings manures (Table 1 ). The total $K$ concentration was likewise clearly highest in the pelleted straw manure. The water soluble $\mathrm{N}$ concentration was markedly lower in the wood shavings manure than in the peat and pelleted straw manures. Water soluble $\mathrm{N}$ comprised around $15 \%$ of the total $\mathrm{N}$ in the wood shavings and pelleted straw manures and almost $30 \%$ in the peat manure. On average $20 \%$ of the soluble $\mathrm{N}$ in the composted manures occurred as $\mathrm{NH}_{4}-\mathrm{N}$, whereas the proportion of $\mathrm{NO}_{3}-\mathrm{N}$ was $65 \%$ in the peat manure, $25 \%$ in the pelleted straw manure and less than $1 \%$ in the wood shavings manure. As in the fresh manures, the water soluble $\mathrm{P}$ of the composted manures occurred totally as inorganic $\mathrm{PO}_{4}-\mathrm{P}$. The water soluble $\mathrm{P}$ comprised $60 \%$ of the total manure $P$ in the peat manure, $50 \%$ in the wood shavings manure and $35 \%$ in the pelleted straw manure.

Table 1. Total and water soluble (1:60) nutrient concentrations ( $\mathrm{g} \mathrm{kg}^{-1}$ dry matter) of fresh and composted horse manures with different bedding materials. The results of clean beddings are means of three replicates \pm standard deviation. The results of the manures are means of four replicates. Standard errors (SE) and least significant differences (LSD) within columns are shown in italics.

\begin{tabular}{|c|c|c|c|c|c|}
\hline & \multicolumn{3}{|c|}{$\begin{array}{c}\text { Total conc. } \\
\text { ( } \mathrm{g} \mathrm{kg}^{-1} \text { dry matter) }\end{array}$} & \multicolumn{2}{|c|}{$\begin{array}{l}\text { Water soluble conc. } \\
\text { (g kg-1 dry matter) }\end{array}$} \\
\hline & $\mathrm{N}$ & $P$ & K & $\mathrm{N}$ & $P$ \\
\hline \multicolumn{6}{|l|}{ Clean bedding } \\
\hline Peat & $8.7 \pm 0.2$ & $0.3 \pm 0.1$ & $<0.7$ & $0.4 \pm 0.1$ & $0.07 \pm 0.00$ \\
\hline Wood shavings & $0.6 \pm 0.0$ & $<0.1$ & $<0.7$ & \pm 0.0 & $0.02 \pm 0.00$ \\
\hline Pelleted straw & $9.1 \pm 0.4$ & $1.4 \pm 0.1$ & $8.5 \pm 0.1$ & $0.4 \pm 0.1$ & $0.34 \pm 0.08$ \\
\hline \multicolumn{6}{|l|}{ Fresh manure } \\
\hline Peat & 14.3 & 2.2 & 14.3 & 3.8 & 1.2 \\
\hline Wood shavings & 10.2 & 2.0 & 14.0 & 3.8 & 1.2 \\
\hline Pelleted straw & 14.8 & 2.7 & 16.3 & 4.6 & 1.3 \\
\hline$S E / L S D$ & $1.0 / 3.4$ & $0.1 / 0.5$ & $0.6 / 2.0$ & $0.4 / 1.5$ & $0.1 / 0.4$ \\
\hline \multicolumn{6}{|l|}{$\begin{array}{l}\text { Composted } \\
\text { manure }\end{array}$} \\
\hline Peat & 15.5 & 2.7 & 16.5 & 4.2 & 1.6 \\
\hline Wood shavings & 13.8 & 3.3 & 21.0 & 2.1 & 1.7 \\
\hline Pelleted straw & 28.8 & 6.3 & 37.0 & 4.7 & 2.2 \\
\hline$S E / L S D$ & $0.7 / 2.3$ & $0.2 / 0.8$ & $1.0 / 3.6$ & $0.5 / 1.6$ & $0.2 / 0.5$ \\
\hline
\end{tabular}

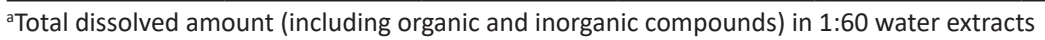

\section{Compostability}

The temperatures of the manure piles started to decrease immediately after the boxes were moved from the stable to outdoor winter temperatures at the end of the one-week collection period and from mid March to early May the masses were frozen (Fig. 1). The mean outdoor daily temperatures increased above $0{ }^{\circ} \mathrm{C}$ from mid April. In May, the manure temperatures begun to increase sharply peaking around $30^{\circ} \mathrm{C}$ in the manures containing peat, $30-50{ }^{\circ} \mathrm{C}$ in those with wood shavings and $40-60{ }^{\circ} \mathrm{C}$ in the ones containing pelleted straw. Aerating by turning initiated further temperature peaks especially in the manures containing pelleted straw but in August, the temperatures of all manure piles decreased to below $20^{\circ} \mathrm{C}$. 


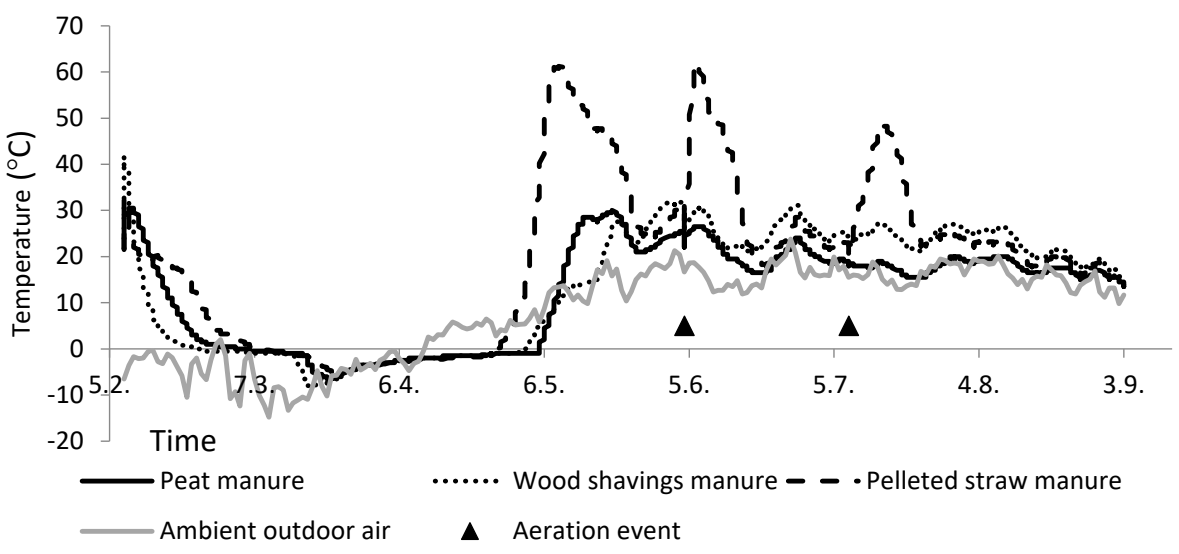

Fig. 1. Temperature $\left({ }^{\circ} \mathrm{C}\right)$ inside $0.5 \mathrm{~m}^{3}$ piles of horse manure with different bedding materials and in the ambient outdoor air during 7-months of composting in Feb - Sep 2013. The temperatures of the manures were recorded in every four hours in the middle part of the piles. The results shown represent the third replicates of the study. The mean daily ambient air temperatures were recorded at a meteorological station of Jokioinen located approximately $10 \mathrm{~km}$ from the composting facility.

During composting, the total dry mass of each manure pile decreased (Table 2). The decrease was highest (50\%) in the pelleted straw manure followed by wood shavings manure (30\%) and peat manure (20\%). Composting had a significant effect on the manure volume weight only in wood shavings manure, in which the volume weight increased by nearly $20 \%$. Total $\mathrm{C}$ concentration of the manures tended to decrease slightly, whereas no significant loss of $\mathrm{N}$ could be detected. The $\mathrm{C}: \mathrm{N}$ ratio clearly decreased in the wood shavings and pelleted straw manures, whereas the $\mathrm{NH}_{4}-\mathrm{N}: \mathrm{NO}_{3}-\mathrm{N}$ ratio showed a significant decrease in the peat and pelleted straw manures. In the fresh manures, the dry matter content was $28 \pm 2 \%$ in the peat manure, $32 \pm 2 \%$ in the wood shavings manure and $34 \pm 3 \%$ in the pelleted straw manure. The corresponding values in the composted manures were $25 \pm 2 \%$, $27 \pm 1 \%$ and $28 \pm 3 \%$.

Table 2. Dry mass, volume weight, $\mathrm{C}$ concentration, total $\mathrm{N}$ content, $\mathrm{C}: \mathrm{N}$ ratio and $\mathrm{NH}_{4}-\mathrm{N}: \mathrm{NO}_{3}-\mathrm{N}$ ratio in fresh horse manures with different bedding materials (initial values) and the change in these characteristics during composting. The values are averages of four replicates with standard error (SE) and $p$ value of the pairwise $t$ test at the 0.05 significance level.

\begin{tabular}{|c|c|c|c|c|c|}
\hline & & \multirow{2}{*}{$\begin{array}{l}\text { Initial value in fresh } \\
\text { manure }\end{array}$} & \multirow{2}{*}{$\begin{array}{l}\text { Mean change during } \\
\text { composting }\end{array}$} & \multicolumn{2}{|c|}{ Parameters for pairwise $t$ test } \\
\hline & & & & SE & $p$ \\
\hline \multirow{3}{*}{$\begin{array}{l}\text { Total dry mass } \\
\text { (kg) }\end{array}$} & Peat & 60 & -11 & 1.0 & 0.002 \\
\hline & Wood shavings & 51 & -16 & 0.3 & $<0.001$ \\
\hline & Pelleted straw & 82 & -39 & 4.0 & 0.002 \\
\hline \multirow{3}{*}{$\begin{array}{l}\text { Volume weight } \\
\left(\mathrm{g} \mathrm{dw}^{-1}\right)\end{array}$} & Peat & 89 & -1.1 & 1.0 & 0.4 \\
\hline & Wood shavings & 72 & 13 & 3.4 & 0.03 \\
\hline & Pelleted straw & 106 & 8.7 & 19 & 0.4 \\
\hline \multirow{3}{*}{$\begin{array}{l}\text { C conc. } \\
\text { (\%) }\end{array}$} & Peat & 46 & -0.5 & 0.1 & 0.03 \\
\hline & Wood shavings & 46 & -2.4 & 1.2 & 0.1 \\
\hline & Pelleted straw & 45 & -4.4 & 0.4 & 0.002 \\
\hline \multirow{3}{*}{$\begin{array}{l}\mathrm{N} \text { content } \\
(\mathrm{g})\end{array}$} & Peat & 865 & -93 & 92 & 0.4 \\
\hline & Wood shavings & 518 & -38 & 23 & 0.2 \\
\hline & Pelleted straw & 1187 & 40 & 143 & 0.8 \\
\hline \multirow[t]{3}{*}{$\mathrm{C}: \mathrm{N}$} & Peat & 33 & -3.9 & 3.1 & 0.3 \\
\hline & Wood shavings & 45 & -13 & 2.0 & 0.007 \\
\hline & Pelleted straw & 31 & -17 & 3.2 & 0.01 \\
\hline \multirow[t]{3}{*}{$\mathrm{NH}_{4}-\mathrm{N}: \mathrm{NO}_{3}-\mathrm{N}$} & Peat & 532 & -531 & 78 & 0.007 \\
\hline & Wood shavings & 276 & -221 & 147 & 0.2 \\
\hline & Pelleted straw & 491 & -475 & 64 & 0.005 \\
\hline
\end{tabular}


The total nutrient concentrations ( $\mathrm{N}, \mathrm{P}$ and $\mathrm{K}$ ) of the manures tended to increase during composting roughly in proportion to the loss of dry mass (Table 3). Similarly, the water soluble P concentrations increased and no change was observed in the proportion of soluble P from total P. The water soluble $\mathrm{N}$ concentrations, in contrast, showed no significant change in the peat and pelleted straw manures and a marked decrease in the wood shavings manure. Consequently, the proportion of soluble $\mathrm{N}$ from total $\mathrm{N}$ decreased except in the peat manure.

Table 3. Total N, P and $\mathrm{K}$ concentrations, water soluble $(1: 60) \mathrm{N}$ and $\mathrm{P}$ concentrations and the proportions of water soluble $\mathrm{N}$ and $P$ from the total amounts in fresh horse manures with different bedding materials (initial values) and the change in these characteristics during composting. The values are averages of four replicates with standard error (SE) and $p$ value of the pairwise $\mathrm{t}$ test at the 0.05 significance level.

\begin{tabular}{|c|c|c|c|c|c|}
\hline & & \multirow{2}{*}{$\begin{array}{l}\text { Initial value in fresh } \\
\text { manure }\end{array}$} & \multirow{2}{*}{$\begin{array}{l}\text { Mean change during } \\
\text { composting }\end{array}$} & \multicolumn{2}{|c|}{ Parameters for pairwise $t$ test } \\
\hline & & & & SE & $p$ \\
\hline \multirow{3}{*}{$\begin{array}{l}\text { Total } N \text { conc. } \\
\left(\mathrm{g} \mathrm{kg}^{-1} \mathrm{dw}\right)\end{array}$} & Peat & 14 & 1.3 & 1.3 & 0.4 \\
\hline & Wood shavings & 10 & 3.6 & 0.7 & 0.01 \\
\hline & Pelleted straw & 15 & 14 & 1.5 & 0.003 \\
\hline \multirow{3}{*}{$\begin{array}{l}\text { Total P conc. } \\
\left(\mathrm{g} \mathrm{kg}^{-1} \mathrm{dw}\right)\end{array}$} & Peat & 2.2 & 0.5 & 0.1 & 0.006 \\
\hline & Wood shavings & 2.0 & 1.4 & 0.2 & 0.007 \\
\hline & Pelleted straw & 2.7 & 3.5 & 0.2 & $<0.001$ \\
\hline \multirow{3}{*}{$\begin{array}{l}\text { Total K conc. } \\
\left(\mathrm{g} \mathrm{kg}^{-1} \mathrm{dw}\right)\end{array}$} & Peat & 14 & 2.3 & 0.5 & 0.02 \\
\hline & Wood shavings & 14 & 7.0 & 0.9 & 0.005 \\
\hline & Pelleted straw & 16 & 21 & 0.9 & $<0.001$ \\
\hline \multirow{3}{*}{$\begin{array}{l}\text { Soluble N } \\
\text { conc. }^{a} \\
\left(\mathrm{~g} \mathrm{~kg}^{-1} \mathrm{dw}\right)\end{array}$} & Peat & 3.8 & 0.4 & 0.2 & 0.08 \\
\hline & Wood shavings & 3.8 & -1.7 & 0.4 & 0.02 \\
\hline & Pelleted straw & 4.6 & 0.1 & 0.8 & 0.9 \\
\hline \multirow{3}{*}{$\begin{array}{l}\text { Soluble P } \\
\text { conc. }^{a} \\
\left(\mathrm{~g} \mathrm{~kg}^{-1} \mathrm{dw}\right)\end{array}$} & Peat & 1.2 & 0.4 & 0.1 & 0.004 \\
\hline & Wood shavings & 1.2 & 0.6 & 0.2 & 0.05 \\
\hline & Pelleted straw & 1.3 & 1.0 & 0.2 & 0.01 \\
\hline \multirow{3}{*}{$\begin{array}{l}\text { Proportion of } \\
\text { soluble } \mathrm{N} \text { from } \\
\text { total N (\%) }\end{array}$} & Peat & 26 & 0.7 & 1.7 & 0.7 \\
\hline & Wood shavings & 37 & -22 & 2.1 & 0.002 \\
\hline & Pelleted straw & 31 & -15 & 4.8 & 0.05 \\
\hline \multirow{3}{*}{$\begin{array}{l}\text { Proportion of } \\
\text { soluble P from } \\
\text { total P (\%) }\end{array}$} & Peat & 55 & 3.6 & 1.8 & 0.1 \\
\hline & Wood shavings & 58 & -6.6 & 3.0 & 0.1 \\
\hline & Pelleted straw & 46 & -10 & 4.3 & 0.1 \\
\hline
\end{tabular}

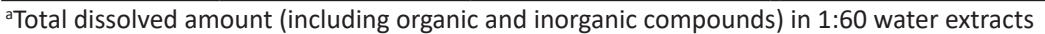

\section{$\mathrm{N}$ and $\mathrm{P}$ leaching during rainfall}

In comparison of the fresh manures, wood shavings manure lost the greatest proportion of its total $\mathrm{N}$ content within the percolated water of the simulated rainfall (Table 4). However, no similar difference could be seen in the $\mathrm{N}$ concentrations of the leachates since the wood shavings manure let through more water ( $500 \mathrm{ml})$ than the pelleted straw manure $(450 \mathrm{ml})$ and peat manure $(240 \mathrm{ml})$. On the contrary, after composting, the wood shavings manure tended to lose less $\mathrm{N}$ than the peat and pelleted straw manures. In the leachates from fresh manure, $\mathrm{NH}_{4}-\mathrm{N}$ dominated (40-70\%) and the proportion of $\mathrm{NO}_{3}-\mathrm{N}$ was marginal $(<1 \%)$, whereas the $\mathrm{N}$ in leachates from composted manure was mostly in $\mathrm{NO}_{3}-\mathrm{N}$ form (50-70\%) and only 5-20\% of the soluble $\mathrm{N}$ was acquired as $\mathrm{NH}_{4}-\mathrm{N}$.

The leaching losses of $\mathrm{P}$ were greatest from the peat manure, regarding both fresh and composted manure (Table $5)$. Wood shavings and pelleted straw manures were rather similar in regard to $P$ leaching under simulated rainfall. The $\mathrm{P}$ in the leachates was mostly (80\%) inorganic $\mathrm{PO}_{4}-\mathrm{P}$. 
Table 4. Leaching losses of $\mathrm{N}$ from different types of manure under simulated rainfall. The results are means of four replicates. Standard errors (SE) and least significant differences (LSD) within columns are shown in italics.

\begin{tabular}{lccc}
\hline & $\begin{array}{c}\text { N concentration in the } \\
\text { percolated water } \\
\left(\mathrm{mg} \mathrm{l}^{-1}\right)\end{array}$ & $\begin{array}{c}\text { Total amount of N leached } \\
\left(\mathrm{mg} \mathrm{kg}^{-1} \text { manure } \mathrm{dw}\right)\end{array}$ & $\begin{array}{c}\text { Proportion of leached N } \\
\text { from manure total N } \\
(\%)\end{array}$ \\
\hline Fresh manure & 786 & 740 & 5 \\
Peat & 492 & 1156 & 11 \\
Wood shavings & 628 & 880 & 6 \\
Pelleted straw & $77 / 266$ & $158 / 545$ & $1.0 / 3.6$ \\
SE/LSD & 1054 & & 9 \\
Composted manure & 287 & 1368 & 4 \\
Peat & 1270 & 541 & 6 \\
Wood shavings & $174 / 603$ & 1702 & $1.3 / 4.3$ \\
Pelleted straw & $291 / 1006$ & 9 \\
SE/LSD & & & \\
\hline
\end{tabular}

Table 5. Leaching losses of $P$ from different types of manure under simulated rainfall. The results are means of four replicates. Standard errors (SE) and least significant differences (LSD) within columns are shown in italics.

\begin{tabular}{lccc}
\hline & $\begin{array}{c}\text { P concentration in the } \\
\text { percolated water } \\
(\mathrm{mg} / \mathrm{l})\end{array}$ & $\begin{array}{c}\text { Total amount of P leached } \\
\left(\mathrm{mg} \mathrm{kg}^{-1} \text { manure } \mathrm{dw}\right)\end{array}$ & $\begin{array}{c}\text { Proportion of leached } \mathrm{P} \\
\text { from manure total P } \\
(\%)\end{array}$ \\
\hline Fresh manure & 342 & 303 & 14 \\
Peat & 69 & 162 & 8 \\
Wood shavings & 100 & 139 & 5 \\
Pelleted straw & $17 / 60$ & $36 / 126$ & $1.2 / 4.1$ \\
SE/LSD & & & 23 \\
Composted manure & 477 & 639 & 12 \\
Peat & 201 & 381 & 7 \\
Wood shavings & 338 & 454 & $2.4 / 8.2$ \\
Pelleted straw & $38 / 131$ & $95 / 327$ & \\
SE/LSD & & & \\
\hline
\end{tabular}

\section{Incubation}

The changes in soluble inorganic $\mathrm{N}\left(\mathrm{NH}_{4}-\mathrm{N}+\mathrm{NO}_{3}-\mathrm{N}\right)$ concentrations during 48-d incubation in the soils amended with fresh and composted manures are presented after subtracting the corresponding $\mathrm{N}$ concentrations in control soils incubated with $\mathrm{NH}_{4} \mathrm{NO}_{3}$ addition only to discern the effect of the manures (Fig. 2). Immobilization of soluble $\mathrm{N}$ introduced within the fresh manure additions (decrease in soluble $\mathrm{N}$ concentration) was observed with all manure types (Fig. 2a). The $\mathrm{N}$ concentrations seemed to exhibit an immobilization - mineralization - immobilization cycle, which was more evident in the peat and pelleted straw manure amended soils than in the ones containing wood shavings manure. At the end of the incubation, roughly half of the initial soluble $\mathrm{N}$ content introduced with the wood shavings manure remained in the soil, whereas in the soils containing peat and pelleted straw manures, the soil soluble $\mathrm{N}$ concentrations were at the same level with the control soils.

In the incubation with composted manures, the curves illustrating changes in the soil soluble $\mathrm{N}$ concentration followed the same shapes than in the corresponding soils with fresh manures (Fig. 2b). However, for the pelleted straw and wood shavings manures, the initial decrease in soil soluble $\mathrm{N}$ was not as steep as for the fresh manures, and at the end of the incubation these soils exhibited net mineralization. In the soils amended with wood shavings manure, the soluble $\mathrm{N}$ concentration doubled from the initial level, and in the soils amended with pelleted straw 
manure an increase of $20 \%$ in the soluble $\mathrm{N}$ was observed. In the soils amended with composted peat manure, the end soil soluble $\mathrm{N}$ concentration was roughly half from that in the beginning.

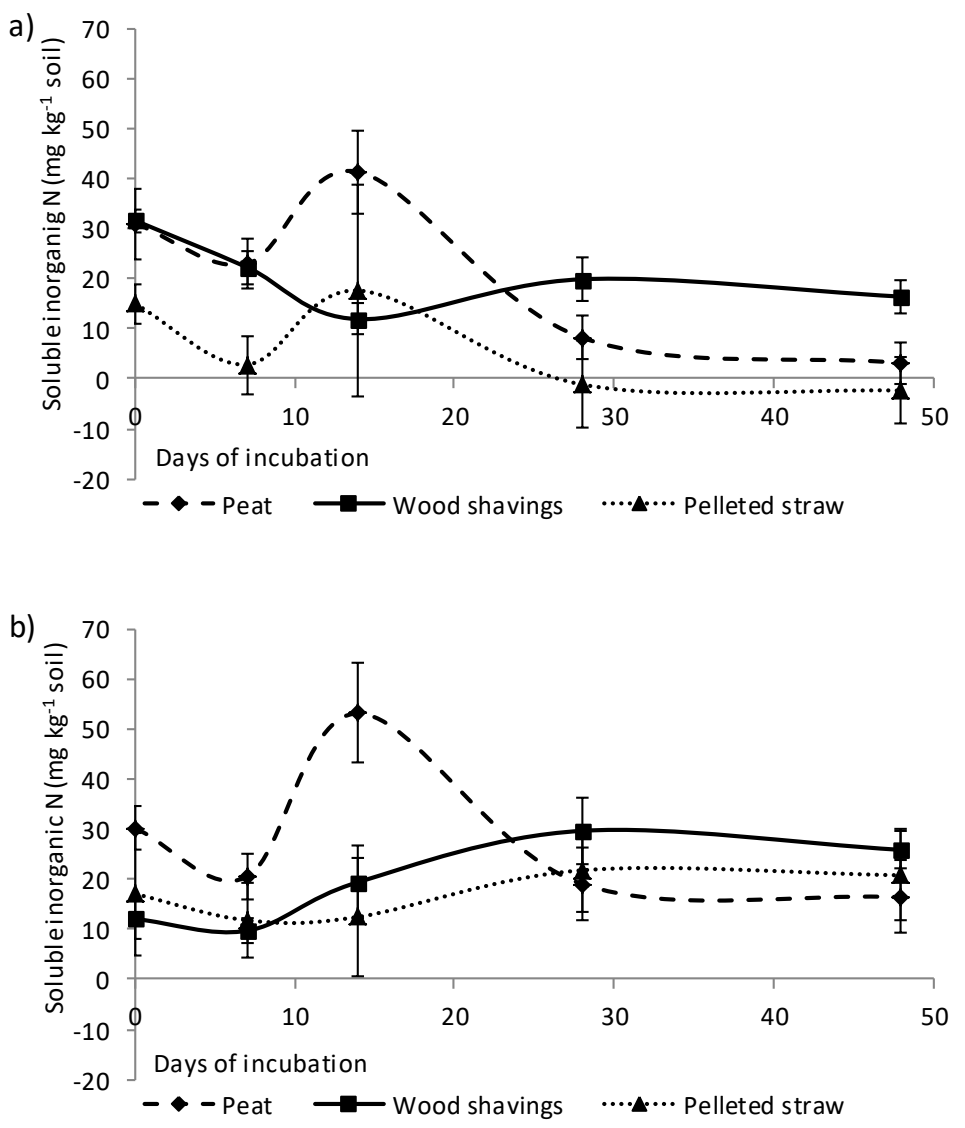

Fig. 2. The effect of fresh (a) and composted (b) horse manure with different bedding materials on the soluble inorganic $\mathrm{N}\left(\mathrm{NH}_{4}-\mathrm{N}+\mathrm{NO}_{3}-\mathrm{N}\right)$ concentrations in soil during 48 -days of incubation. The results are means of four replications \pm standard deviation. The background $\mathrm{N}$ concentrations in soil incubated without manure amendment have been subtracted from the results.

\section{Discussion}

Since bedding material makes up the bulk of horse manure, its nutrient composition can be expected to affect the manure nutrient contents. Consequently, the relatively high total $\mathrm{P}$ and $\mathrm{K}$ concentrations of pelleted straw and low $\mathrm{N}$ concentration of wood shavings were reflected in the corresponding concentrations in the manures.

A horse weighing 400-600 kg excretes on average 19-30 kg dung and urine per day, which contains on estimate 70-150 g N, 10-30 g P and 20-50 g K (Lawrence et al. 2003). The amount of nutrients excreted by the horse in dung and urine depend highly on the nutrition and feed quality (Graham-Thiers and Bowen 2011, Ögren 2013, Ögren et al. 2014, Fowler et al. 2015, Trottier et al. 2016), optimization of which is an important tool in reducing excess nutrient load from horse operations. Averages of around 500 horse manure samples analyzed in Finland in a commercial laboratory, Eurofins Viljavuuspalvelu Oy, between 2005 and 2009 were $15 \mathrm{~g} \mathrm{~kg}^{-1} \mathrm{dw}_{\text {for }}$ total N, $3 \mathrm{~g} \mathrm{~kg}^{-1}$ $\mathrm{dw}$ for total $\mathrm{P}$ and $16 \mathrm{~g} \mathrm{~kg}^{-1} \mathrm{dw}$ for total $\mathrm{K}$ (Viljavuuspalvelu 2016). The corresponding concentrations in our study tended to be slightly lower than these nationwide averages. An application rate of $9 \mathrm{t} \mathrm{dw} \mathrm{ha-1}$ (roughly $30 \mathrm{t} \mathrm{ha}^{-1}$ fresh weight) of the fresh manures produced in our study would provide in total 90-130 kg N, 20-25 kg P and 125 $-150 \mathrm{~kg} \mathrm{~K}$. However, the amount of water soluble $\mathrm{N}$ would be only $35-40 \mathrm{~kg}$. According to the present incubation study, practically all the soluble $\mathrm{N}$ of fresh peat and pelleted straw manure and half of that in the wood shavings manure would be immobilized after incorporation into soil. Thus the short-term $\mathrm{N}$ fertilizer effect of the manures would be close to zero or even negative. The mineralization rate of $\mathrm{N}$ from manures and composts is overall low 
(Hartz et al. 2000, Eghball et al. 2002). Manure P is, in contrast to N, mostly plant available (Eghball et al. 2002, Ögren et al. 2014). The plant availability of manure K is likewise generally high (Wen et al. 1997, Eghball et al. 2002).

Composting provides a potential way to increase the value of horse manure since it increases nutrient concentrations and decreases C: $\mathrm{N}$ ratio due to decomposition of organic matter (Bernal et al. 2009). According to the indices we used to assess the composting process, namely heat generation, dry mass and $\mathrm{C}$ loss, and changes in $\mathrm{C}: \mathrm{N}$ and $\mathrm{NH}_{4}-\mathrm{N}: \mathrm{NO}_{3}-\mathrm{N}$ ratios, the compostability of the studied manures could be ranked pelleted straw $>$ wood shavings $>$ peat. Comparisons of compostability of differently bedded animal manures have produced somewhat contradictory results. For example, in the studies of Airaksinen et al. (2001) peat-bedded horse manure was found to compost more efficiently than manure containing wood shavings, straw, hemp, linen, sawdust or newspaper, whereas N'Dayegamiye and Isfan (1991) found wood shavings manure to have superior composting characteristics in comparison to sawdust and peat moss manures. Swinker et al. (1997) found sawdust to compost more readily than phone book paper or straw but Komar et al. (2012) concluded that straw-based materials are better suited for composting than wood-based materials. These discrepancies can be explained by differences a) in the particle size of the substrates used, b) the proportion between dung, urine and the bedding material (C:N ratio), c) moisture content and d) process control, namely aeration (Gajalakshmi and Abbasi 2008).

In our study, heat generation by the microbial activity was not sufficient in any of the manure piles to resist the winter's frost. Even during the spring and summer time, the temperature increased high enough for pathogen (Gajalakshmi and Abbasi 2008) as well as weed seed and animal parasite destruction (Johansen et al. 2013) only in the manure containing pelleted straw bedding and the maximum heat peaks in all the manures were relatively short in duration. In several other studies, no great differences in the temperature development between manure composts containing different bedding materials have been observed (Airaksinen et al. 2001, Larney et al. 2008, Komar et al. 2012). High compost heats have been maintained successfully despite extreme winter air temperatures (Larney and Hao 2007) and the thermal thresholds for eliminating pathogens ( $>55{ }^{\circ} \mathrm{C}$ for $15 \mathrm{~d}$ ) easily exceeded (Larney et al. 2008). However, in some experiments the temperatures adequate for manure hygienization have not been reached (Swinker et al. 1997, Komar et al. 2012).

The wintertime difficulties in keeping up microbial activity in our composts might have been related to the small size $\left(0.5 \mathrm{~m}^{3}\right)$ of the manure piles. Moisture content of the manures was likely adequate throughout the experiment. We processed the manures in their inherent moisture content of around $70 \%$ while ideal moisture for allowing metabolic and physiological activities of microorganisms yet maintaining adequate oxygen supply is considered to be $50-60 \%$ (Gajalakshmi and Abbasi 2008). Clear spikes in the manure temperatures following turning of the masses indicate that oxygen supply limited the composting process. Even though composting occurs to some extent naturally, efficient composting requires careful process control (Bernal et al. 2009).

Despite the probably slightly suboptimal conditions in our study, the total dry mass losses of $18 \%$ for peat manure, $31 \%$ for wood shavings manure and $48 \%$ for pelleted straw manure during composting are in agreement with the results of previous studies. Larney and Hao (2007) reported dry matter losses of 20-30\% during manure composting, Hao et al. (2004) recorded a $30 \%$ dry mass loss for straw-bedded manure and $27 \%$ for wood bedded manure and in the study of Komar et al. (2012), the dry mass reductions were $49 \%$ for pelletized straw manure and $40 \%$ for wood shavings manure. The rate of degradation is dependent on the quality of the $C$ source and the initial C:N ratio of the substrate (Bernal et al. 2009, Gajalakshmi and Abbasi 2008). Labile organic compounds degrade quickly, whereas more recalcitrant compounds decompose slowly. In wood based materials, lignin content is higher than in those composed of straw, which makes the wood-based beddings less biodegradable (Hao et al. 2004). Greater dry mass loss with straw than wood-based beddings has been reported in several studies (Hao et al. 2004, Michel et al. 2004, Larney et al. 2008). High C: $\mathrm{N}$ ratios lead to limiting $\mathrm{N}$ concentrations, wherefore microbial populations remain small and decomposition takes long. An ideal C:N ratio for a substrate to be composted is around 25-35, which was attained for the peat and pelleted straw manures composted in our study. The C:N ratio of mature composts should be less than 20 (Goyal et al. 2005, Bernal et al. 2009), which level we reached only with the pelleted straw manure. Initially high decomposition stage of peat bedding may explain the poor compostability of peat manure in our study.

In cattle manure composting experiments reviewed by Larney and Hao (2007), bulk density of the manures increased 3-4 fold during composting but we found a significant increase only in the bulk density of wood shavings manure, which as fresh had the least dense structure of the manures compared. 
Occurrence of nitrification is one of the indicators of compost maturity though no exact target level of the ratio of $\mathrm{NH}_{4}-\mathrm{N}$ to $\mathrm{NO}_{3}-\mathrm{N}$ can be set (Gajalakshmi and Abbasi 2008). In cattle manure composts the $\mathrm{NH}_{4}-\mathrm{N}: \mathrm{NO}_{3}-\mathrm{N}$ ratio decreased from around 400 to less than one (Larney and Hao 2007). In our study, the variation in $\mathrm{NO}_{3}-\mathrm{N}$ concentrations between replicate samples was considerable, and a substantial difference was found in the proportions of $\mathrm{NO}_{3}-\mathrm{N}$ in the water extracts $(<1 \%)$ and rainfall leachates $(47 \%)$ of composted wood shavings. However, clear decreases in the $\mathrm{NH}_{4}-\mathrm{N}: \mathrm{NO}_{3}-\mathrm{N}$ ratio were observed indicating the most active degradation had ceased.

Composting increased the total nutrient concentrations of all the manures studied, except for the total $\mathrm{N}$ concentration of peat manure, due to loss of dry mass in the process. Our coarse inspection of the $\mathrm{N}$ mass balances over the composting period showed no significant decrease in the total $\mathrm{N}$ content of the composts. Ammonia $\left(\mathrm{NH}_{3}\right)$ volatilization is generally the major pathway for $\mathrm{N}$ losses from manure composts and the gaseous losses can account for around $50 \%$ of the initial total $\mathrm{N}$ of the manure (Michel et al. 2004, Bernal et al. 2009). The C:N ratio of the substrate governs the magnitude of $\mathrm{NH}_{3}$ volatilization since excess $\mathrm{N}$ not immobilized in the microbial biomass is easily lost (Gajalakshmi and Abbasi 2008). Several studies have shown bedding materials rich in available C to reduce $\mathrm{N}$ losses (Fraser and Lau 2000, Hao et al. 2004, Michel et al. 2004, Larney et al. 2008, Bernal et al. 2009). The high bedding material contents of horse manures thus makes them less vulnerable to $N$ volatilization.

The stabilization of organic matter via composting leads to reduced mineralization rates, which slows the release of nutrients but also reduces the potential immobilization of released mineral N (Kirchmann and Bernal 1997, Parkinson et al. 2004, Larney and Hao 2007). Comparison of the N dynamics during incubation of fresh and composted manures in soil demonstrated this effect, except for the peat manure, which composted most poorly. Even though the amounts of $\mathrm{N}$ mineralized from the composted wood shavings and pelleted straw manures during the 48-d incubation were small, the negative fertilizer effect was, however, overcome by the composting process.

In our study, leaching losses of nutrients were avoided by sheltering the manure piles from rainfall but the rate of nutrient release during a rain event was, however, assessed under rain simulation. The rain simulation study resembles water extraction carried out in the analyses of soluble nutrient contents of the manures but in rain simulation, the water retention capacity and structure of the manure, which govern the percolation of water through the manure pile, are emphasized. Our results showed the water retention capacity of peat manure to be considerably higher than that of pelleted straw and wood shavings manures, which is in agreement with the results of Airaksinen et al. (2001). However, the greatest proportional loss of total P occurred in the peat manure. Parvage (2015) found the maximum P-retention capacity of peat, wood chips and wheat straw to be rather similar but only wood chips were able to bind $\mathrm{P}$ leached from horse dung under rain simulation, whereas peat and straw were rather sources of additional $\mathrm{P}$. We found the $\mathrm{N}$ retention capacity of wood shavings manure to be poorer than that of the peat and pelleted straw manures but a decrease in the amount of soluble $\mathrm{N}$ due to $\mathrm{N}$ immobilization during composting reduced the risk of $\mathrm{N}$ leaching from the wood shavings manure. Based on our results, covering the composts and manure storages is recommendable to reduce the losses of nutrients to environment and improve the fertilizer value of horse manure.

\section{Conclusions}

In conclusion, the differences in the total and water soluble $\mathrm{N}$ and $\mathrm{P}$ concentrations were small between the fresh manures studied though the total nutrient contents were lowest in the wood shavings manure. Composting proved to be beneficial since it reduced the manure volume, increased its nutrient concentrations and eliminated $\mathrm{N}$ immobilization after soil application, though the $\mathrm{N}$ fertilizer value of the manures remained low. Pelleted straw manure composted more efficiently than wood shavings manure and peat manure, which showed the weakest composting characteristics. Active aeration was needed to maintain the composting process in all the manure types. Peat manure appeared to be more susceptible to leaching losses of $\mathrm{P}$ under rainfall than manures with wood shavings or pelleted straw. Covering the composts and manure storages is recommendable to reduce the leaching losses of nutrients.

\section{Acknowledgements}

We thank Mr. Aaro Närvänen for his contribution in the rain simulation experiments. The study was funded by the Finnish Ministry of the Environment via the Programme for promoting recycling of nutrients and improving the status of the Archipelago Sea, which is gratefully acknowledged. 


\section{References}

Airaksinen, S. 2006. Bedding and manure management in horse stables. Kuopio University Publications C. Natural and Environmental Sciences 190. $52 \mathrm{p}$.

Airaksinen, S., Heinonen-Tanski, H. \& Heiskanen, M.-L. 2001. Quality of different bedding materials and their influence on the compostability of horse manure. Journal of Equine Veterinary Science 21: 125-130. https://doi.org/10.1016/S0737-0806(01)70108-6

Bernal, M., Alburquerque, J. \& Moral, R. 2009. Composting of animal manures and chemical criteria for compost maturity assessment. A review. Bioresource Technology 100: 5444-5453. https://doi.org/10.1016/j.biortech.2008.11.027

Chen, B., Liu, E., Tian, Q., Yan, C. \& Zhang, Y. 2014. Soil nitrogen dynamics and crop residues. A review. Agronomy for Sustainable Development 34: 429-442. https://doi.org/10.1007/s13593-014-0207-8

EHN 2016. European Horse Network. www.europeanhorsenetwork.eu. Cited 4 November 2016.

Eghball, B., Wienhold, B.J., Gilley, J.E. \& Eigenberg, R.A. 2002. Mineralization of manure nutrients. Journal of Soil and Water Conservation 57: 470-473.

EPMA 2009. The economic and social contribution of horseracing in Europe. www.parimutuel-europe.org.European Pari Mutuel Association. $31 \mathrm{p}$.

Fowler, A.L., Hansen, T.L., Strasinger, L.A., Harlow, B.E. \& Lawrence, L.M. 2015. Phosphorus digestibility and phytate degradation by yearling and mature horses. Journal of Animal Science 93: 5735-5742. https://doi.org/10.2527/jas.2015-9139

Fraser, B.S. \& Lau, A.K. 2000. The effects of process control strategies on composting rate and odor emission. Compost Science and Utilization 8: 274-292. https://doi.org/10.1080/1065657X.2000.10702001

Gajalakshmi, S. \& Abbasi, A. 2008. Solid waste management by composting: State of the art. Critical Reviews in Environmental Science and Technology 38: 311-400. https://doi.org/10.1080/10643380701413633

Goyal, S., Dhull, S.K. \& Kapoor, K.K. 2005. Chemical and biological changes during composting of different organic wastes and assessment of compost maturity. Bioresource Technology 96: 1584-1591.

https://doi.org/10.1016/j.biortech.2004.12.012

Graham-Thiers, P.M. \& Bowen, L.K. 2011. Effect of protein source on nitrogen balance and plasma amino acids in exercising horses. Journal of Animal Science 89: 729-735. https://doi.org/10.2527/jas.2010-3081

Hao, X., Chang, C. \& Larney, F.J. 2004. Carbon, nitrogen balances and greenhouse gas emission during cattle feedlot manure composting. Journal of Environmental Quality 33: 37-44. https://doi.org/10.2134/jeq2004.3700

Hartz, T.K., Mitchell, J.P. \& Giannini, C. 2000. Nitrogen and carbon mineralization dynamics of manures and composts. HortScience 35: 209-212.

Jansson, A. \& Dahlborn, K. 1999. Effects of feeding frequency and voluntary salt intake on fluid and electrolyte regulation in athletic horses. Journal of Applied Physiology 86: 1610-1616.

Johansen, A., Nielsen, H.B., Hansen, C., Andreasen, C., Carlsgart, J., Hauggard-Nielsen, H. \& Roepstorff, A. 2013. Survival of weed seeds and animal parasites as affected by anaerobic digestion at meso- and thermophilic conditions. Waste Management 4: 807812. https://doi.org/10.1016/j.wasman.2012.11.001

Kirchmann, H. \& Bernal, M.P. 1997. Organic waste treatment and C stabilization efficiency. Soil Biology and Biochemistry 29: 17471753. https://doi.org/10.1016/S0038-0717(97)00065-5

Komar, S., Miskewitz, R., Westendorf, M. \& Williams, C.A. 2012. Effects of bedding type on compost quality of equine stall waste: Implications for small horse farms. Journal of Animal Science 90: 1069-1075. https://doi.org/10.2527/jas.2010-3805

Larney, F.J. \& Hao, X. 2007. A review of composting as a management alternative for beef cattle feedlot manure in southern Alberta, Canada. Bioresource Technology 98: 3221-3227. https://doi.org/10.1016/j.biortech.2006.07.005

Larney, F.J., Olson, A.F., Miller, J.J., DeMaere, P.R., Zvomuya, F. \& McAllister, T.A. 2008. Physical and chemical changes during composting of wood chip-bedded and straw-bedded beef cattle feedlot manure. Journal of Environmental Quality 37: 725-735. https://doi.org/10.2134/jeq2007.0351

Lawrence, L., Bicudo, J.R. \& Wheeler, E. 2003. Horse manure characteristics literature and data-base review. Proceedings of the Ninth International Symposium Animal, Agricultural and Food Processing Wastes IX. Raleigh, NC. ASAE, St. Joseph, MI. p. 277284. https://doi.org/10.13031/2013.15262

Michel Jr, F.C., Pecchia, J.A., Rigot, J.R. \& Keener, H.M. 2004. Mass and nutrient losses during composting of dairy manure amended with sawdust or straw. Compost Science and Utilization 12: 323-334. https://doi.org/10.1080/1065657X.2004.10702201

Luke 2017. Feed tables and nutrient requirements. https://portal.mtt.fi/portal/page/portal/Rehutaulukot/feed_tables_english/ nutrient_requirements/horses

N'Dayegamiye, A. \& Isfan, D. 1991. Chemical and biological changes in compost of wood shavings, sawdust and peat moss. Canadian Journal of Soil Science 71: 475-484. https://doi.org/10.4141/cjss91-046

Närvänen, A., Jansson, H., Uusi-Kämppä, J., Jansson, H. \& Perälä, P. 2008. Phosphorus load from equine critical source areas and its reduction using ferric sulphate. Boreal Environment Research 13: 265-274.

Ögren, G. 2013. Phosphorus to horses and cows. Licenciate thesis, Swedish University of Agricultural Sciences, Uppsala, 33 p.

Ögren, G., Holtenius, K. \& Jansson, A. 2014. Phosphorus balance and fecal losses in growing Standardbred horses in training fed forage-only diets. Journal of Animal Science 91: 2749-2755. https://doi.org/10.2527/jas.2012-6048 
Parkinson, R., Gibbs, P., Burchett, S. \& Misselbrook, T. 2004. Effect of turning regime and seasonal weather conditions on nitrogen and phosphorus losses during aerobic composting of cattle manure. Bioresource Technology 91: 171-178. https://doi.org/10.1016/S0960-8524(03)00174-3

Parvage, M.M. 2015. Impact of horse-keeping on phosphorus (P) concentrations in soil and water. Doctoral thesis, Swedish University of Agricultural Sciences, Uppsala. $62 \mathrm{p}$.

Parvage, M.M., Ulen, B. \& Kirchmann, H. 2015. Are horse paddocks threating water quality through excess loading of nutrients? Journal of Environmental Management 147: 306-313. https://doi.org/10.1016/j.jenvman.2014.09.019

Pussinen, S., Korhonen, J., Pölönen, J. \& Varkia, R. 2007. Growing horse sector. Laurea Applied Univerity publications B19. 91 p.

Särkijärvi, S., Hyyppä, S., Saastamoinen, M. \& Karvinen, A. 2004. Effect of peat as bedding material on the welfare and health of horses. In: Järvinen J. (ed.). Wise use of peatlands, vol. 2. p. 1084-1087.

Särkijärvi, S. \& Saastamoinen, M. 2014. Phosphorus and nitrogen excretion of Finnhorse mares with typical Finnish diets. Proc. 7th EWEN. p. 129.

Schryver, H.F., Hintz, H.F. \& Graig, P.H. 1971. Phosphorus metabolism on ponies fed varying levels of phosphorus. Journal of Nutrition 101: 1257-1263.

Sweeten, J.M., Mathers, A.C. 1985. Improving soils with livestock manure. Journal of Soil and Water Conservation 40: 206-210.

Swinker, A.M., Tanner, M.K., Johnson, D.E. \& Benner, L. 1997. Composting characteristics of three bedding materials. Journal of Equine Veterinary Science 18: 462-466. https://doi.org/10.1016/S0737-0806(98)80039-7

Toribio, R.E., Kohn, C.W., Rourke, K.M., Levine, A.L. \& Rosol, T.J. 2007. Effects of hyper-calcemia on serum concentrations of magnesium, potassium, and phosphate and urinary excretion of electrolytes in horses. American Journal of Veterinary Research 68: 543-554. https://doi.org/10.2460/ajvr.68.5.543

Trottier, N.L., Bott, R.C., Woodward, A., Greene, E.A., Williams, C.A., Westendorf, M.L., Swinker, A.M., Mastellar, S.L. \& Martinson, K. 2016. Gastrointestinal nitrogen metabolism of equids and impact on protein requirement. Journal of Equine Veterinary Science 45: 79-86. https://doi.org/10.1016/j.jevs.2016.06.002

Uusi-Kämppä, J., Närvänen, A., Kaseva, J. \& Jansson, H. 2012. Phosphorus and faecal bacteria in runoff from horse paddocks and their mitigation by the addition of P-sorbing materials. Agricultural and Food Science 21: 247-259.

Uusitalo, R. \& Aura, E. 2005. A rainfall simulation study on the relationships between soil test P versus dissolved and potentially available particulate phosphorus forms in runoff. Agricultural and Food Science 14: 335-345.

https://doi.org/10.2137/145960605775897713

Viljavuuspalvelu 2016. Lantatilasto vuosilta 2006-2009. http://viljavuuspalvelu.fi/sites/default/files/sites/default/files/tilastot/ Lantatilas-to\%202005\%20-\%202009.pdf. Cited 25 October 2016.

Wen, G., Winter, J.P., Voroney, R.P. \& Bates, T.E. 1997. Potassium availability with applications of sewage sludge, and sludge and manure composts in field experiments. Nutrient Cycling in Agroecosystems 47: 233-241.

https://doi.org/10.1007/BF01986278 